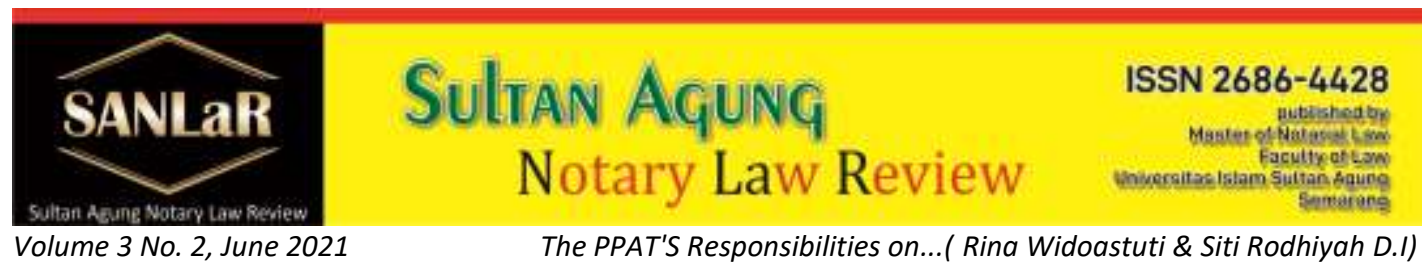

\title{
The PPAT'S Responsibilities on Calculation of Tax Payment Value
}

\author{
Rina Widoastuti ${ }^{*}$ and Siti Rodhiyah Dwi Istinah ${ }^{* *}$ \\ ${ }^{*}$ Faculty of Law, Universitas Islam Sultan Agung (UNISSULA) Semarang, E-mail: \\ rinawidoastuti00@gmail.com \\ ${ }^{* *}$ Faculty of Law, Universitas Islam Sultan Agung (UNISSULA) Semarang, E-mail: \\ rodhiyah@unissula.ac.id
}

\begin{abstract}
In the implementation of the transfer of rights through the buying and selling process, at the stage of calculating the value of tax payments several times, people found that they deliberately and openly asked to reduce the transaction value from the price it should have been, so that tax costs would not be large. This writing aims to determine and analyze the calculation of the value of the sale and purchase of land and/or buildings in Pekalongan Regency, the role and responsibility of PPAT in calculating the value of tax payments based on Perda No. 6 of 2012 Pekalongan Regency. This research approach uses a sociological juridical, namely research through a legal approach and examines laws that have problems in practice. Then analyzed using role theory, responsibility theory, justice theory, and legal certainty theory. The results of the study indicate that the calculation of the value of the sale and purchase of land and/or buildings in Pekalongan Regency is based on calculations that have been determined by the laws and regulations. The role and responsibility of PPAT in calculating the value of tax payments on land and/or building sale and purchase transactions based on Perda Number 6 of 2012 Pekalongan Regency, namely PPAT's obligation in making a deed is first to ensure that the Land and Building Rights Acquisition Fee (BPHTB) has been paid. PPAT's responsibility is to help clients make online submissions on the website provided by the Pekalongan Regency Government.
\end{abstract}

Keywords: Roles; Responsibilities; PPAT; Tax Payment.

\section{Introduction}

Each country has a different source of income. No exception developing countries or developed countries must have sources of income that are used by their countries for the prosperity and welfare of the people. Indonesia is a developing country whose largest revenue comes from taxes. Taxes are a very important source of state revenue in supporting development financing 
originating from within the country. The government in carrying out tax collection must be based on justice and provide legal certainty for taxpayers without viewing taxes as a burden but as a state obligation that must be fulfilled as members of the community who receive services from the government. $^{1}$

Article 23A of the Constitution of the Republic of Indonesia 1945 states that taxes and other levies of a coercive nature for the purposes of the state are regulated by law. Tax is a social phenomenon and only exists in a society. Without society, there can be no tax. ${ }^{2}$ Based on this opinion, it can be seen that the tax comes from the community and for the community. ${ }^{3}$

BPHTB is imposed on the acquisition of land and building rights obtained by individuals or entities related to the transfer of rights to land and/or buildings to be carried out by the appearer. This has been stated in Article 91 paragraph (1) of Act No. 28 of 2009 concerning Regional Taxes and Regional Levies (PDRD Law), namely that the BPHTB has been paid off by the taxpayer. However, what happens if the PPAT does not carry out what is stated in the provisions. Of course, PPAT will be held accountable for the violations he has committed. ${ }^{4}$

PPAT is given the authority to make an authentic deed related to the transfer of rights which is called a deed of sale. The deed of sale and purchase (AJB) is a deed that proves that there has been a transfer of rights from the seller to the buyer. In principle, the sale and purchase of land and buildings is real and cash, where both parties agree, and the agreement is described in an authentic deed made by PPAT, and the costs have been paid off. If the land sale transaction fee has not been paid, then AJB cannot be made. Thus the PPAT's obligation in making the deed is to first make sure that the Land and Building Rights Acquisition Fee (BPHTB) has been paid by showing proof of the BPHTB deposit. ${ }^{5}$

\footnotetext{
${ }^{1}$ Dina Erlinda, et al, "Pelaksanaan Verifikasi Peralihan Hak Atas Tanah \& Bangunan (Bphtb) Di Kabupaten Bogor", Jurnal Notarius, Vol. 13 No. 2, 2020,, p. 947

2 Rochmat Soemitro \& Dewi Kania Sugiharti, Asas \& Dasar Perpajakan, Ed. Revisi Bandung: PT Refika Aditama, 2010, p. 1.

${ }^{3}$ Miyasto, Sistem Perpajakan, Yogyakarta: PT. Liberty, 1997, p. 3.

${ }^{4}$ Suryanto, Bambang Hermanto, \& Mas Rasmini, "Analisis Potensi Bea Perolehan Hak Atas Tanah \& Bangunan Sebagai Salah Satu Pajak Daerah," Jurnal Pemikiran \& Penelitian Administrasi Bisnis \& Kewirausahaan 3, No. 3 (2018): 273-281

${ }^{5}$ Saktisila Widjono, W, (2013), Tesis, “Kajian Yuridis Terhadap Pelaksanaan Pasal 91 ayat (1) Undang-Undang Nomor 28 Tahun 2009 Tentang Pajak Daerah \& Retribusi Daerah Di Kota Medan", Magister Kenotariatan, Fakultas Hukum, Universitas Sumatera Utara, p. 6.
} 
In Pekalongan Regency, regulations for calculating the value of tax payments have been stipulated which are regulated in Pekalongan Regency Regional Regulation Number 6 of 2012 concerning Amendments to Pekalongan Regency Regional Regulation Number 10 of 2010 concerning Regional Taxes (Perda No. 6 of 2012). The existence of the Regional Regulation is in accordance with the Letter of the Minister of Finance of the Republic of Indonesia Number S-666/PK/2012 dated August 8, 2012 regarding Approval for the Implementation of Rural and Urban Land and Building Tax Collection (PBB-P2) in 2013. 6 of 2012 as a form of compliance with the mandate of Act No. 28 of 2009 concerning Regional Taxes and Regional Levies which gives greater authority to regions in the field of taxation in the form of maximum tariff increases, expansion of tax objects,

At the end of 2018, the Pekalongan Regency Government in this case the Regional Finance Agency (BKD) in collaboration with the Bank launched an online tax payment service application including BPHTB. This service makes taxpayers, PPAT, and BKD officers do not need to meet face to face to prevent leakage that has been experienced so far because several parties have collaborated so that the BPHTB paid is below the price it should be.

Based on the description of the background explaining the payment of land and/or building taxes, the authors are interested in studying and researching further by taking the title Role-Responsibility of PPAT in Calculation of the Value of Tax Payments Based on Perda No. 6 of 2012 Pekalongan Regency.

Based on the description of the background that has been described, the authors formulate the problem as follows:

a. How is the value of the sale and purchase transaction of land and/or buildings calculated in Pekalongan Regency?

b. What is the role and responsibility of PPAT in calculating the value of tax payments on land and/or building sale and purchase transactions based on Perda Number 6 of 2012 Pekalongan Regency?

\section{Research Method}

Researchers use legal research methods with a juridical approachsociological, the research specification used is descriptive analysis, the data source comes from primary data and secondary data. Methods of data collection were carried out through field research, library research, and document studies. This writing is analyzed qualitatively by using the analysis 
knife of role theory, responsibility theory, justice theory, and legal certainty theory.

\section{Results and Discussion}

\subsection{Calculation of the Value of Land and/or Building Sale and Purchase Transactions in Pekalongan Regency}

Implementation of collection and or payment of Customs on Acquisition of Rights on Land and Buildings (BPHTB) since the enactment of Act No. 21 of 1997 concerning Customs on Acquisition of Land and Building Rights, which has been amended by Act No. 20 of 2000 concerning Amendments to Act No. 21 of 1997 concerning Customs for Acquisition of Land and Building Rights, which was later called the BPHTB Law, was originally a central tax, as well as the enactment of Act No. 28 of 2009 concerning Regional Taxes and Regional Levies (PDRD Law), which later became a regional tax, still causing problems. for people who carry out legal acts of transferring land rights, such as buying and selling, grants or inheritance who often do not understand the provisions in terms of how to collect and how to determine the amount of BPHTB they have to pay. ${ }^{6}$, which each level of government has the authority to collect taxes. In carrying out the authority to collect BPHTB as a regional tax, a regional regulation is made with the approval of the DPRD, because it involves the rights, obligations and assets of the local people. ${ }^{7}$

The payment of taxes in the sale and purchase of land and/or buildings requires an important role and linkage from the BPKD. The authority of the BPKD in carrying out the calculation of the sale and purchase tax of land and/or buildings, namely: ${ }^{8}$

a. determine the value of the NJOP of land and buildings in accordance with the law

b. determine the reduction of NJOPTKP according to the transaction (for sale and purchase, grant, auction, PHB the reduction is IDR $60,000,000.00$ ), except for inheritance of IDR 300,000,000.00

c. approve the value of the land sale and purchase transaction

\footnotetext{
${ }^{6}$ Adrian Sutedi, 2008, Hukum Pajak \& Retribusi Daerah, Ghalia Indonesia, Bogor, p. 13

${ }^{7}$ Murtir Jeddawi, 2008, Implementasi Kebijakan Otonomi Daerah (Analisis Kewenangan, Kelembagaan, managemen Kepegawaian, \& Peraturan Daerah), Total Media, Yogyakarta p. 39.

8 Interview with Arif Wahyu Hidayat as Head of Planning and Determination at the Regional Financial Management Agency Office, on March 10, 2021
} 
d. reject the sale and purchase price of land / NJOP whose value is too low / not in accordance with fairness.

The basis for imposition of BPHTB is the acquisition value of the tax object (NPOP). NPOP from buying and selling is the transaction value, if the transaction value is unknown or lower than the NJOP then the land and building tax (PBB) used is the imposition of Land and Building Tax (PBB) in the year the acquisition occurs, the basis for the imposition used is the PBB NJOP. The amount of the BPHTB rate is $5 \%$ of the NJOP, the amount of tax to be paid depends on these two things. If the NJOP is higher than the transaction value then the NJOP is used and vice versa if the Transaction is higher than the NJOP then the transaction value is used (according to the Law). In Pekalongan Regency, the tax calculation is stated in Regional Regulation Number 6 of 2012 and implemented by Regulation of the Regent of Pekalongan Number 65 of 2017 concerning the classification of the market value of the earth's surface market object in the form of land and buildings as the basis for the imposition of BPHTB. Where the NJOP in the Perbup is the basis for calculating the BPHTB tax (minimum limit). If the NJOP per meter in the Perbup is not appropriate or is still too low, the BPKD asks for the permeter price to be increased above the Perbup at a reasonable price, namely the BPKD by conducting Verlap (Field Verification), by asking directly the relevant agencies, namely the village (village apparatus) or Confirm the price directly to the seller. ${ }^{9}$

The explanation related to the calculation of BPHTB for more details, the author presents with examples of cases accompanied by the Deed of Sale and Purchase (AJB) made by PPAT against buying and selling carried out in Pekalongan Regency.

\section{POSITION CASE}

Haryoso sold a plot of land with proof of ownership of SHM No. $00831 /$ Sumurjomblangbogo with an area of $588 \mathrm{~m} 2$. Haryoso sold the land with the approval of his wife, Herlina. The land is located in Sumurjomblangbogo Village, Bojong District, Pekalongan Regency, Central Java with the following boundaries:

North : Jl. village

${ }^{9}$ Ibid. 


\section{East : Hj. Asriningsih \\ South side : Moh. Ikhsan \\ West Side : Eko Hernowo}

The land was purchased by Hendarto, a person who was born in Pekalongan but domiciled at Jalan Palem Kuning XVI Block I.18 Number 10, Rt. 005, Rw. 024, Pejuang Village, Medan Satria District, Bekasi City. Hendarto bought the land at a price of IDR 350,000,000.00 (three hundred and fifty million rupiah).

In Pekalongan Regency, the NPOP of the earth's surface in the form of land and buildings has been determined as the basis for the imposition of BPHTB. Pekalongan Regent Regulation Number 65 of 2017 concerning Classification of Market Value of Earth Surface Market Objects in the Form of Land and Buildings as the basis for imposition of BPHTB. Here the author presents the data:

Table 1. The Market Value of Earth Surface Tax Objects in the Form of Land and Buildings as the Basis for Imposition of Taxes on Acquisition of Rights on Land and Buildings

\begin{tabular}{|c|c|c|c|c|c|c|c|c|}
\hline $\begin{array}{l}\text { DISTRICT } \\
\text { CODE }\end{array}$ & $\begin{array}{c}\text { VILLA } \\
\text { GE } \\
\text { CODE }\end{array}$ & SUBDISTRICT & $\begin{array}{l}\text { VILLAGE / } \\
\text { NEIGHBORHOOD }\end{array}$ & BLOCK & STREET NAME & $\begin{array}{l}\text { KD } \\
\text { ZNT }\end{array}$ & $\begin{array}{l}\text { NJOP } \\
\text { PER } M^{2}\end{array}$ & $\begin{array}{c}\text { MARKET } \\
\text { PRICE / } \\
\text { M2 }\end{array}$ \\
\hline 110 & 003 & BOJONG & $\begin{array}{l}\text { JOMBLANG BOGO } \\
\text { WELL }\end{array}$ & 032 & KP IGIR BATOK BATOK & AM & 36,000 & 108.000 \\
\hline 110 & 003 & BOJONG & $\begin{array}{l}\text { JOMBLANG BOGO } \\
\text { WELL }\end{array}$ & 032 & TEGALAN BLOCK BLOCK TEAK & AM & 36,000 & 108.000 \\
\hline 110 & 003 & BOJONG & $\begin{array}{l}\text { JOMBLANG BOGO } \\
\text { WELL }\end{array}$ & 032 & TEGALAN BLOCK BLOCK TEAK & $\mathrm{AO}$ & 7.150 & 21,450 \\
\hline 110 & 003 & BOJONG & $\begin{array}{l}\text { JOMBLANG BOGO } \\
\text { WELL }\end{array}$ & 032 & TEGALAN BLOCK BLOCK TEAK & AP & 14,000 & 42,000 \\
\hline 110 & 003 & BOJONG & $\begin{array}{l}\text { JOMBLANG BOGO } \\
\text { WELL }\end{array}$ & 032 & LONDHO ALAS BLOCK TEGALAN & $\mathrm{AO}$ & 7.150 & 21,450 \\
\hline 110 & 003 & BOJONG & $\begin{array}{l}\text { JOMBLANG BOGO } \\
\text { WELL }\end{array}$ & 032 & LONDHO ALAS BLOCK TEGALAN & AP & 14,000 & 42,000 \\
\hline 110 & 003 & BOJONG & $\begin{array}{l}\text { JOMBLANG BOGO } \\
\text { WELL }\end{array}$ & 032 & $\begin{array}{l}\text { WEST BATOK IGIR } \\
\text { TEGALAN }\end{array}$ & $\mathrm{AO}$ & 7.150 & 21,450 \\
\hline 110 & 003 & BOJONG & $\begin{array}{l}\text { JOMBLANG BOGO } \\
\text { WELL }\end{array}$ & 032 & $\begin{array}{llll}\text { WEST BATOK } & \text { IGIR } & \text { BLOCK } \\
\text { TEGALAN } & & & \\
\end{array}$ & AP & 14,000 & 42,000 \\
\hline 110 & 003 & BOJONG & $\begin{array}{l}\text { JOMBLANG BOGO } \\
\text { WELL }\end{array}$ & 032 & $\begin{array}{llll}\text { TEGALAN } & \text { BLOCK } & \text { LOR } & \text { ALAS } \\
\text { LONDHO } & & & \end{array}$ & $\mathrm{AO}$ & 7.150 & 21,450 \\
\hline 110 & 003 & BOJONG & $\begin{array}{l}\text { JOMBLANG BOGO } \\
\text { WELL }\end{array}$ & 032 & $\begin{array}{llll}\text { TEGALAN } & \text { BLOCK } & \text { LOR } & \text { ALAS } \\
\text { LONDHO } & & & \end{array}$ & AP & 14,000 & 42,000 \\
\hline
\end{tabular}

The calculation of BPHTB for the sale and purchase of land must be completed with the following conditions: 


\section{Fc. Certificate}

2. UN SPPT

3. Fc. Buyer's ID

4. Fc. Seller's ID

The applicant can request a power of attorney through PPAT or be managed by himself in order to find out the value of the tax that must be fulfilled (paid) for the sale and purchase of land. Judging by the Certificate and SPPT PBB, from the SPPT we can see the NOP is where the block is, from there we can see the NJOP price per meter, after knowing the price per meter, it can be calculated by the following calculation:

Buying and selling land at a price of IDR 350,000,000.00

Sales Tax PPH : $2.5 \%$ x land price

$2.5 \% \times 350,000,000=\operatorname{IDR} 8,750.000,00$

Surface area : $588 \mathrm{M}^{2}$, NJOP of land (legal basis of Perbup) per meter = IDR $108,000.00$

The land price : Area $588 \times 108,000=$ IDR 63,504,000.00

Based on the example described above, the NJOP value with a higher transaction price is the transaction price. Therefore, the highest value is used for calculating BPHTB with the following calculation:

Highest Price - Pekalongan Regency NPOPTKP:

IDR $350,000,000-60,000,000=$ IDR $290,000,000$

\section{BPHTB to be paid:}

IDR $290,000,000 \times 5 \%=$ IDR16,820,000.00

Once calculated, the next step is to register online to BPHTB website (using PPAT Password) if authorized by PPAT. For completeness of the file submitted to the BPKD directly. Furthermore, the PPAT concerned comes to the BPKD to take the files that have been in the ACC then the PPAT 
conveys to the applicant (taxpayer) that the tax can be paid by the applicant himself or his PPAT. The transaction value is paid through Bank BPD Central Java.

BPKD verifies (checked) by BPKD officers, if the calculation requirements are in accordance with the NJOP value (seen through zoning matching, based on verlap, matching mapped with data base, check plot, aerial photography (drone), google map) is appropriate, the file is complete (such as administrative requirements, Fc. Certificate, Fc. SPPT PBB, Fc. KTP of the seller and buyer) then there are no problems and the file is in the ACC. Then the PPAT can view the file online without having to come to the BPKD. After that, the BPKD officer conveys to the applicant that the tax can be paid. Then, the applicant can make a payment at the Central Java Bank (BPD), after being paid, ask the BPKD to ask for verification/authorization of the officer. With proof of validation/billing code that BPHTB tax has been paid.

If the file is rejected by the BPKD officer on the grounds that it was rejected because the file is incomplete (SPPT that is not in accordance with the location of the land, or is lacking, a statement of difference in the name of the owner of the name of the land between the SPPT and a certificate, lack of an ID card, etc.) then it must be completed first.

If it is rejected on the grounds that the price is not appropriate (because the BPKD considers the NJOP to be too low, the price is not in accordance with the market price of the land (after checking based on zoning etc., also in the NJOP Perbup, the BPKD considers it to be still low) then the $B P K D$ is ordered to raise it price.

The PPAT party conveys to the applicant (taxpayer) to confirm the price to the BPKD, it can be done by means of the PPAT himself who comes (through his office staff), or the applicant himself directly goes to the BPKD to confirm what the appropriate price is for the land. If agreed, then proceed to be verified. ${ }^{10}$

Based on the description above, it can be seen that there are still taxpayers who make price confirmations (negotiations) between taxpayers and BPKD officers to determine the transaction value.

\footnotetext{
${ }^{10}$ Ibid.
} 
According to the BPKD, what was being done was not bargaining (negotiation) but price confirmation. According to the BPKD, the price is not appropriate or not right (NJOP is still too low), and maybe people here are still not honest about the transaction value, (still being lowered), people are still trying to explore it first. ${ }^{11}$

The BPKD explained that if the value submitted was not in accordance with the stipulated price, the price had to be increased in order to get the appropriate value and not deviate from the laws and regulations. The community understands that accepting what has been agreed in accordance with the reasonable price means it is finished, and the next step is to submit it for verification by the BPKD.

3.2. PPAT Roles and Responsibilities in Calculation of Tax Payment Value for Land and/or Building Sale and Purchase Transactions Based on Regional Regulation Number 6 of 2012 Pekalongan Regency

Before we buy a plot of land, it is necessary to do it carefully, because many things that are less profitable in the future for the buyer, for example land in a state of dispute or land located in an area that is subject to control and so on.

The procedure for implementing the sale and purchase of land and/or buildings according to the UUPA with its implementing regulations, can simply be described as follows:

a. Prospective buyers and sellers agree to carry out a sale and purchase to determine everything for themselves, regarding land and its price.

b. Prospective buyers and sellers come alone or require other people with a power of attorney, to appear before the Land Deed Making Officer (PPAT) (Head of District, Notary or other appointed by the government).

c. In the event that the land to be sold has not been recorded (not yet certified), the presence of the Village Head or a member of the Village Government is required who will not only act as a witness, but also guarantee that the land to be sold is indeed the property of the seller and he is authorized to sell it.

d. In the event that the land to be sold has been recorded (has already certificate) attended by two witnesses, it does not have to

\footnotetext{
11 Ibid.
} 
be the Village Head and members of the village government. However, if the Land Deed Making Official (PPAT) considers it necessary (if there is any doubt about the authority of the person conducting the sale and purchase), then the PPAT may request the presence of the Village Head and a member of the Village Government from the location of the land to be sold.

e. If the land being sold has been recorded, the seller must submit a certificate, but if it has not been recorded, a certificate must be made instead from the Head of the Defense Office stating that the land has not been recorded.

f. After PPAT feels that the requirements are sufficient, there are no obstacles (for example there is a dispute) and there is no hesitation, then PPAT makes the Bali Land Sale Deed.

g. Furthermore, with the existence of the deed, the PPAT will arrange the registration until it gets a certificate.

PPAT is given the authority to make an authentic deed related to the transfer of rights which is called a deed of sale and purchase. ${ }^{12}$ The deed of sale and purchase (AJB) is a deed that proves that there has been a transfer of rights from the seller to the buyer. In principle, the sale and purchase of land and buildings is real and cash, where both parties agree, and the agreement is described in an authentic deed made by PPAT, and the costs have been paid off. If the land sale transaction fee has not been paid, then AJB cannot be made. Thus the PPAT's obligation in making the deed is to first make sure that the Land and Building Rights Acquisition Fee (BPHTB) has been paid by showing proof of the BPHTB deposit. ${ }^{13}$

Act No. 28 of 2009 concerning Regional Taxes and Regional Levies (hereinafter abbreviated as UUPDRD) states that related to BPHTB Taxes are regional taxes whose authority is collected by the City/Regency government. Tax is an important role for a country as a source of income in the state treasury which is used for the purposes of government and development activities to achieve public welfare. ${ }^{14}$

PPAT plays an important role in the sale and purchase of land, which indirectly has helped the Head of Regency/City BPN to carry out activities related to land. PPAT's position is very important in the delivery of

\footnotetext{
${ }^{12}$ Ronal Ravianto \& Amin Purnawan, (2017), “Peran Pejabat Pembuat Akta Tanah (PPAT) Dalam Pemungutan Bea Perolehan Hak Atas Tanah \& Bangunan (BPHTB) Dengan Pendekatan Self Assessment System. Jurnal Akta, Vol. 4 No. 4, p.5

${ }^{13}$ Saktisila Widjono, W, Loc. Cit.

${ }^{14}$ Miyasto, Loc. Cit.
} 
transaction prices as the basis for determining BPHTB to the public. The sale and purchase deed is made when the object and the transaction price have been agreed upon and paid in full by the buyer, but before that, tax verification must be carried out as the main requirement in the land sale and purchase transaction ${ }^{15}$ However, PPAT does not directly play a role in its verification.

According to Linton, role theory describes social interaction in terms of actors who play according to what is determined by culture. In accordance with this theory, role expectations are shared understandings that guide individuals to behave in everyday life. According to this theory, someone who has a certain role. PPAT in the implementation of the sale and purchase of land also has a role to make a deed of sale and purchase of land, but in calculating the value of the sale and purchase of land, PPAT has a role to check again, ensure that the taxpayer has paid his BPHTB, and open or assist the tax payment website.

The government carries out regional development by using tax proceeds which are a source of regional funding. Thus, for regional progress, regional revenues must be further increased. This is so that the provision of services by the government to the community in meeting regional needs is increasing. BPHTB is a tax levied under the PDRD Law. Based on Article 95 paragraph (1) of the PDRD Law, it states "Taxes are determined by Regional Regulation".

The BPHTB tax is one of the taxes that meets the criteria for regional taxes to increase regional income and regional accountability. Thus, the tax must be optimized by examining the object and applying the Standard Operating Procedure (SOP) of BPHTB and the Regional Technical Implementation Unit (UPTD) of BPHTB.

Based on Article 24 paragraph (1) of Act No. 21 of 1997 in conjunction with Act No. 20 of 2000 PPAT can only sign AJB when the parties submit proof of tax payment, and AJB is made after the clean check process at the BPN office is complete and BPHTB and PPH taxes have been paid by the buyer and seller. BPHTB tax payments can be made through a bank or

\footnotetext{
${ }^{15}$ Yunita Budi Chrissanni \& Amin Purnawan, (2017), Peranan PPAT Dalam Pemungutan Bea Perolehan Hak Tanah \& Bangunan (BPHTB) On Line Atas Transaksi Jual Beli Tanah \& Bangunan Di Kabupaten Pekalongan. Jurnal Akta, Vol. 4 No. 3, p. 3.
} 
post office. The deed of sale and purchase will not be issued if the BPHTB tax has not been paid. ${ }^{16}$

PPAT is tasked with providing legal certainty related to its authority as an authentic deed maker. In its duties, it contains 2 main functions of PPAT, namely first, PPAT is responsible for legal certainty regarding the validity of a legal binding, secondly, PPAT has the authority by attribution in creating legal certainty and protection for all parties. ${ }^{17}$ Etymologically the word "responsibility" comes from English, namely "Responsibility" which means responsibility, responsibility or those who have responsibility. Liability is an obligation for all things that happen and to provide remedies for losses caused.

The role and responsibility of PPAT in calculating the value of land sale and purchase transactions in Pekalongan Regency based on Perda $12 / 2017$, namely PPAT in making the Deed is to ensure that the BPHTB payments owed must be repaid first by showing proof of BPHTB deposit (SSB). ${ }^{18}$

The technical involvement of PPAT in the calculation of the value of the BPHTB transaction is that the PPAT behaves according to the existing normative rules in accordance with the tax law. In this calculation, if the NJOP value is higher than the sale and purchase transaction, the NJOP is used for calculation and vice versa if the transaction is higher of NJOP used is the transaction value.

PPAT is directly involved in helping register online for BPHTB payments through the website that has been provided by Pekalongan Regency. The following are the responsibilities of a notary in submitting a BPHTB payment online:

a. calculate according to existing rules, incoming files to BPKD are received by BPKD

b. PPAT (staff) submit administrative requirements (photocopy of certificate, photocopy of SPPT PBB of the land object, photocopy of ID card of buyer and seller).

\footnotetext{
${ }^{16}$ Harnita, dkk, 2019, "Tanggung Jawab PPAT dalam Penetapan Nilai Transaksi Jual Beli Tanah \& Bangunan di Kota Banda Aceh", Jurnal Magister Hukum Udayana, Vol. 8 No. 3, p. 363

${ }^{17}$ Yoyon Mulyana Darusman, 2016, Kedudukan notaris sebagai pejabat pembuat akta otentik \& sebagai pejabat pembuat akta tanah. ADIL: Jurnal Hukum, Vol. 7 No. 1, p. 36

${ }^{18}$ Interview with PPAT Bachtiar, SH, on Jl. Hero, Kajen, Pekalongan Regency. On March 22, 2021 
c. waiting for the results of the BPKD Verification through the website.

PPAT can only sign the deed of transfer of rights to land and/or buildings after the taxpayer submits proof of tax payment. PPAT must report the making of the deed to the Regent through the authorized official no later than the following 10 (ten) months.

PPAT should have good morality and not be easily influenced by temptations in carrying out the applicable law. That is because a PPAT is a trusted public official, so PPAT must prioritize accuracy and precision when carrying out his/her position as well as possible, considering that the PPAT profession is a professional public official who can also be sanctioned.

If the PPAT violates the provisions of the legislation, it will be subject to administrative sanctions in the form of a fine of IDR 7,500,000,000.00 (seven million five hundred thousand rupiah) for each violation.

The community also has a role in submitting the transaction price as the basis for the BPHTB tax which must be submitted to the PPAT for making a deed of sale and purchase. The deed of sale and purchase is made when it has been agreed upon and the transaction price for the land has been settled. But first, BPHTB tax verification must be carried out which is one of the transfer of rights. This is because every legal action in the form of transfer of rights to land and buildings must be able to show evidence that the BPHT tax has been paid for the PPAT concerned.

In the opinion of the author, PPAT in carrying out the calculation of the value of buying and selling transactions has carried out its responsibilities, namely helping clients make online submissions on the website provided by the Pekalongan Regency Government. Hans Kelsen in his theory of legal responsibility states that a person is legally responsible for a certain act or that he bears legal responsibility means that he is responsible for a sanction in the event of a contrary act. PPAT violating the provisions of the legislation will be subject to administrative sanctions in the form of fines for each violation. PPAT in carrying out his work must also be careful and thorough so that all actions can be accounted for. Hans Kelsen also stated that failure to exercise due care required by law is called "negligence"; and error is usually seen as another kind of "fault" (culpa) although not as severe as the fault which is fulfilled by anticipating and wishing, with or without malicious intent, harmful consequences. 


\section{Closing}

The calculation of the value of the sale and purchase of land and/or buildings in Pekalongan Regency is based on the calculations that have been determined by the legislation. The basis for imposition of BPHTB is the acquisition value of the tax object (NPOP), with a rate of $5 \%$ of the NJOP, the amount of tax that must be paid depends on these two things. Calculation of BPHTB is formulated to reduce NJOPTKP according to the transaction (for sale and purchase, grants, auctions, PHB is reduced by IDR $60,000,000.00$ ), except for inheritance of IDR $300,000,000.00$. If the NJOP is higher than the transaction value, then the NJOP is used and vice versa if the Transaction is higher than the NJOP, the transaction value is used. The role and responsibility of PPAT in calculating the value of tax payments on land and/or building sale and purchase transactions based on Perda Number 6 of 2012 Pekalongan Regency, namely PPAT's obligation in making a deed is first to ensure that the Land and Building Rights Acquisition Fee (BPHTB) has been paid by showing proof of deposit BPHTB. PPAT must report the making of the deed to the Regent through the authorized official no later than the following 10 (ten) months. PPAT's responsibility is to help clients make online submissions on the website provided by the Pekalongan Regency Government. PPAT must report the making of the deed to the Regent through the authorized official no later than the following 10 (ten) months. PPAT's responsibility is to help clients make online submissions on the website provided by the Pekalongan Regency Government. PPAT must report the making of the deed to the Regent through the authorized official no later than the following 10 (ten) months. PPAT's responsibility is to help clients make online submissions on the website provided by the Pekalongan Regency Government.

\section{References}

Journal:

[1] Dina Erlinda, dkk, 2020, "Pelaksanaan Verifikasi Peralihan Hak Atas Tanah \& Bangunan (Bphtb) Di Kabupaten Bogor", Jurnal Notarius, Vol. 13 No. 2.

[2] Harnita, dkk, 2019, "Tanggung Jawab PPAT dalam Penetapan Nilai Transaksi Jual Beli Tanah \& Bangunan di Kota Banda Aceh", Jurnal Magister Hukum Udayana, Vol. 8 No. 3.

[3] Ronal Ravianto \& Amin Purnawan, 2017, "Peran Pejabat Pembuat Akta Tanah (PPAT) Dalam Pemungutan Bea Perolehan Hak Atas Tanah \& Bangunan (BPHTB) Dengan Pendekatan Self Assessment System. Jurnal Akta, Vol. 4 No. 4. 
[4] Suryanto, Bambang Hermanto, \& Mas Rasmini, 2018, "Analisis Potensi Bea Perolehan Hak Atas Tanah \& Bangunan Sebagai Salah Satu Pajak Daerah," Jurnal Pemikiran \& Penelitian Administrasi Bisnis \& Kewirausahaan 3, No. 3.

[5] Yoyon Mulyana Darusman, 2016, Kedudukan notaris sebagai pejabat pembuat akta otentik \& sebagai pejabat pembuat akta tanah. ADIL: Jurnal Hukum, Vol. 7 No. 1.

[6] Yunita Budi Chrissanni \& Amin Purnawan, 2017, Peranan PPAT Dalam Pemungutan Bea Perolehan Hak Tanah \& Bangunan (BPHTB) On Line Atas Transaksi Jual Beli Tanah \& Bangunan Di Kabupaten Pekalongan. Jurnal Akta, Vol. 4 No. 3.

Books:

[1] Adrian Sutedi, 2008, Hukum Pajak \& Retribusi Daerah, Ghalia Indonesia, Bogor.

[2] Miyasto, 1997, Sistem Perpajakan, PT. Liberty, Yogyakarta.

[3] Murtir Jeddawi, 2008, Implementasi Kebijakan Otonomi Daerah (Analisis Kewenangan, Kelembagaan, managemen Kepegawaian, \& Peraturan Daerah), Total Media, Yogyakarta.

[4] Rochmat Soemitro \& Dewi Kania Sugiharti, Asas \& Dasar Perpajakan, Ed. Revisi Bandung: PT Refika Aditama, 2010.

[5] Saktisila Widjono, W, (2013), Tesis, "Kajian Yuridis Terhadap Pelaksanaan Pasal 91 ayat (1) Undang-Undang Nomor 28 Tahun 2009 Tentang Pajak Daerah \& Retribusi Daerah Di Kota Medan", Magister Kenotariatan 